\title{
Post-Paleocene Tertiary Rocks and Quaternary Volcanic Ash of the Wet Mountain Valley, Colorado
}

GEOLOGICAL SURVEY PROFESSIONAL PAPER 868

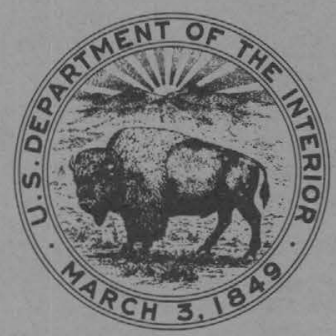





\section{Post-Paleocene Tertiary Rocks and Quaternary Volcanic Ash of the Wet Mountain Valley, Colorado}

By GLENN R. SCOTT and RICHARD B. TAYLOR

GEOLOGICAL SURVEY PROFESSIONAL PAPER 868

A stratigraphic and structural study of sedimentary and volcanic rocks along a graben in south-central Colorado

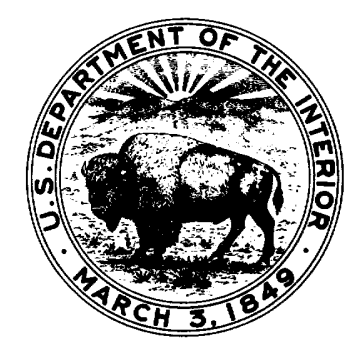

UNITED STATES GOVERNMENT PRINTING OFFICE, WASHINGTON : 1975 
UNITED STATES DEPARTMENT OF THE INTERIOR

ROGERS C. B. MORTON, Secretary

GEOLOGICAL SURVEY

v. E. McKelvey, Director

Library of Congress Cataloging in Publication Data

Scott, Glenn Robert, $1918-$

Post-Paleocene Tertiary rocks and Quaternary volcanic ash of the Wet Mountain Valley, Colorado.

(Geological Survey Professional Paper 868)

Bibliography: p.

Supt. of Docs. No.: I 19.16:868

1. Petrology-Colorado-Wet Mountain Valley. 2. Volcanism-Colorado-Wet Mountain Valley. 3. Geology, Stratigraphic -Cenozoic.

I. Taylor, Richard Bartlett, joint author. II. Title. III. Series: United States Geological Survey. Professional Paper 868. QE445.C64S36 557.88'51

74-22109

For sale by the Superintendent of Documents, U.S. Government Printing Office

$$
\text { Washington, D.C. } 20402 \text { - Price } \$ 1.55
$$

(paper cover) 


\section{CONTENTS}

Abstract

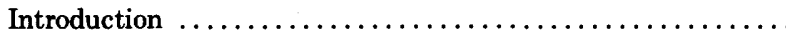

Acknowledgments $\ldots \ldots \ldots \ldots \ldots \ldots \ldots \ldots \ldots \ldots \ldots \ldots$

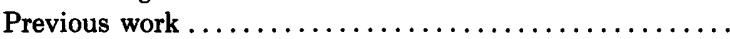

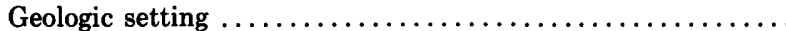

Eocene sedimentary rocks

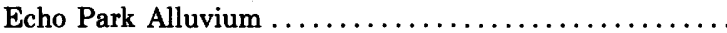

Huerfano Formation and related rocks

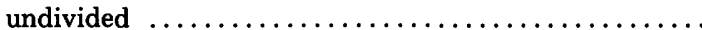

Devils Hole Formation $\ldots \ldots \ldots \ldots \ldots \ldots \ldots \ldots \ldots \ldots \ldots$

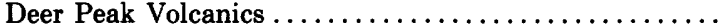

Volcanic rocks at Grape Creek

Volcanic rocks at Rosita
Page

1

1

Oligocene and Miocene intrusive and extrusive volcanic rocks undivided-Continued

Volcanic rocks near Silver Cliff ................ 9

Water-laid ash at Johnson Gulch ............... 9

Volcanics of the Thirtynine Mile volcanic field ........ 10

Goat Creek ....................... 10

Hillside $\ldots \ldots \ldots \ldots \ldots \ldots \ldots \ldots \ldots \ldots \ldots \ldots \ldots . \ldots \ldots \ldots$

Oak Creek .......................... 11

Little Cottonwood Creek ................ 11

Middle and upper Tertiary Santa Fe(?) Formation .......... 11

Pleistocene Pearlette ash $. \ldots \ldots \ldots \ldots \ldots \ldots \ldots \ldots \ldots \ldots \ldots, 13$

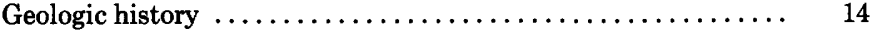

References cited ........................ 15

\section{ILLUSTRATIONS}

Plate 1. Geologic map of post-Paleocene Tertiary rocks and Quaternary volcanic ash along the Wet Mountain Valley graben,

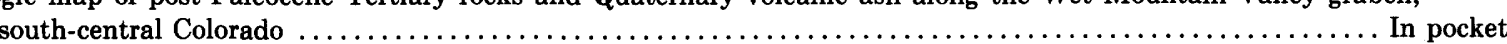

Figure 1. Index map of area near Wet Mountain Valley, showing places and faults mentioned in text $\ldots \ldots \ldots \ldots \ldots \ldots \ldots$

TABLE 



\title{
POST-PALEOCENE TERTIARY ROCKS AND QUATERNARY VOLCANIC ASH OF THE WET MOUNTAIN VALLEY, COLORADO
}

\author{
By Glenn R. Scott and Richard B. Taylor
}

\begin{abstract}
The Wet Mountain Valley in south-central Colorado is a tectonic basin bounded by the Sangre de Cristo Range and the Wet Mountains. Eocene deposits are prevolcanic arkosic coarse Echo Park Alluvium that we correlate with Farisita Conglomerate, which may be a facies of the Huerfano Formation. We believe that these deposits of the Echo Park occupy the lower part of a fill in the Wet Mountain Valley and surely extend southward into Huerfano Park where they merge with the Huerfano Formation and its partial lateral equivalent, the Farisita Conglomerate. The Huerfano and Farisita are interpreted by us as sedimentary facies representing distinctive lithologies from separate source areas intermixed to varying degrees by stream action. The onset of volcanism in early Oligocene time is marked between Rosita and Huerfano Park by the Devils Hole Fornıation, here containing arkosic tuffaceous sandstones and pumice conglomerates as originally defined, but now assigned to the early Oligocene. The Devils Hole interfingers with the oldest rocks of the Deer Peak Volcanics, an Oligocene unit here named to include the Deer Peak stock and lava flows, lahars, and volcanic sediments derived from this center. Other similar volcanic rocks are present at the Rosita and Silver Cliff centers along the east flank of the Wet Mountain Valley, and small amounts of locally derived volcanic material interfinger with distantly derived rocks along the southern margin of the Thirtynine Mile volcanic field and in the Wet Mountain Valley as far south as Hillside and Goat Creek. The uppermost Tertiary deposit in the Wet Mountain Valley is a salmon-pink basin-fill alluvium, the Santa Fe(?) Formation of Miocene and Pliocene age.

Camel bones, Camelops huerfanensis (Cragin), discovered before 1889 and assigned, according to then-current usage, to the Pliocene (now early Pleistocene), have been long used as a guide for age assignment of Tertiary beds of Huerfano Park. These can now be confidently assigned to the type $O$ Pearlette ash in a terrace gravel of Yarmouth age rather than to the Tertiary deposits.
\end{abstract}

\section{INTRODUCTION}

While mapping the geology of the Wet Mountains and Wet Mountain Valley, Colo., in 1968, we studied the stratigraphic sequence, correlation, and age of the outcropping Tertiary rocks in order to establish units for the Pueblo 1:250,000 quadrangle. This report summarizes this work and reevaluates prior conclusions concerning origin, age, and correlation of the deposits. Geochronologic dating has helped in correlating the deposits with contemporaneous deposits in nearby areas. Some of the formations were first described as much as
80 years ago, and histories of past usage are presented where pertinent.

\section{ACKNOWLEDGMENTS}

We are indebted to many geologists for information used here. The geology of Wet Mountain Valley was discussed with Peter L. Siems, David S. McCulloch, and Robert D. MacNish, and copies of their doctoral dissertations (Siems at Colorado School of Mines and McCulloch and MacNish at University of Michigan) helped us in mapping the geology and in understanding the stratigraphy. A University of Michigan dissertation on the Devils Hole area by J. S. Guyton, J. R. Hutton, and G. E. Sokolsky, which was given to us by Guyton, discusses the Devils Hole Formation in detail and gives a measured section that was of great value to us. Thomas A. Steven, Rudy C. Epis, and Charles E. Chapin discussed with us the relationships of rocks considered here and provided information on volcanic rocks elsewhere in Colorado. Unpublished mapping by William N. Sharp near Silver Cliff and Rosita was helpful to us in understanding the structure and stratigraphy of the volcanic rocks in those areas. Ray E. Wilcox and Glen A. Izett examined several samples of volcanic ash for us and gave advice on the meaning of the Pearlette family ash beds in Huerfano Park and near Westcliffe. G. Edward Lewis and Robert W. O'Donnell of the U.S. Geological Survey collected vertebrate fossils from several localities in the general area, and Lewis identified and showed the stratigraphic significance of vertebrate fossils from several of the Tertiary basin-fill deposits in the Pueblo 1:250,000 quadrangle. We are grateful to Frank C. Whitmore, Jr., U.S. Geological Survey, Washington, D.C., for locating in the National Museum some of the vertebrate fossils collected by R. C. Hills and for helping us determine the source beds of these fossils. Lloyd A. Hershey, U.S. Geological Survey, supplied information from drill holes in Wet Mountain Valley concerning texture and thickness of the Santa Fe(?) Formation. Carl Hedge, U.S. Geological Survey, dated Tertiary rocks in the Rosita volcanic field; John Obradovich dated rocks in the Thirtynine Mile volcanic field. 


\section{PREVIOUS WORK}

At least 75 reports have touched upon the Tertiary deposits of this area, and many of these are cited in this report. The earliest geological examination of the Tertiary deposits of this area (Arkansas Valley near Salida) for which a report exists was by F. V. Hayden in 1873 . Other reports of the Hayden and Wheeler territorial surveys discussed some aspects of the Tertiary deposits of the north end of Wet Mountain Valley and Huerfano Park. The pioneer work on Eocene deposits was by R. C. Hills between 1888 and 1902; the gross aspect of his work has been modified very little, and most of his rock names are still used. He had an excellent understanding of the relationships of tectonism and sedimentation. The fossils of the Huerfano Formation were first studied by H. F. Osborn and his colleagues, then by G. G. Simpson, and later by Peter Robinson. The Tertiary volcanic rocks were first studied by Whitman Cross, who described the volcanic rocks near Silver Cliff and Rosita in 1890 and 1896. R. C. Epis and his students, C. E. Chapin, P. L. Siems, and others, restudied the Tertiary volcanic rocks at Silver Cliff and Rosita and in the north end of the Wet Mountain Valley in the 1960's. In 1937 W. S. Burbank and E. N. Goddard showed the relationship between tectonic history and deposition of the Tertiary beds. Beginning in the early 1950 's, R. B. Johnson and his colleagues in the U.S. Geological Survey and a large group of graduate students at the University of Michigan have completed many reports on the geology of Huerfano Park; a summary volume by the University of Michigan group is now in preparation. Dissertations by $\mathrm{D}$. S. McCulloch and R. D. MacNish from the University of Michigan consider the surficial geology of the Wet Mountain Valley and some correlative deposits in Huerfano Park.

\section{GEOLOGIC SETTING}

The area discussed here is one of several structural basins that intervene between mountain ranges in southcentral Colorado (fig. 1). The San Luis Valley on the west is followed in succession eastward by the Sangre de Cristo Range, the Wet Mountain Valley, the Wet Mountains, and the Great Plains. Most of the Tertiary sedimentary deposits in the Wet Mountain Valley lie in a linear southeast-trending basin that extends from near Coaldale southward beyond Promontory Divide into Huerfano Park. Pleasant Valley along the Arkansas River northwest of Coaldale seems to be a detached segment of the same structural trend. To the north, a further structural and sedimentational extension of this basin trend is the Antero basin in the southwest corner of South Park. The upper Arkansas Valley from Salida northward to Leadville is a similar structural and sedimentational basin containing Tertiary sedimentary and volcanic rocks. The upper Arkansas Valley is a northward structural extension of the Rio Grande trench, which includes the San Luis Valley to the south (Van Alstine, 1968). Most of the Tertiary intrusive and extrusive volcanic rocks described here lie along the faulted edge of the Wet Mountain Valley and on the westward-sloping parts of the De Weese Plateau and the Wet Mountains.

In the area discussed here, major fault zones have controlled the location, shape, and size of the mountain ranges and intervening structural basins and in places have localized volcanic issue. Many of these faults appear to have had Precambrian ancestry. A major fault zone showing Quaternary movement (Scott, 1970) bounds the west flank of the Sangre de Cristo Range (pl. 1), and the Alvarado fault zone separates this range from the Tertiary Wet Mountain Valley graben to the east. The Westcliffe fault and the Ilse and Wet Mountain faults (pl. 1) controlled late Tertiary uplift of the northern part of the Wet Mountains.

Volcanic rocks of Oligocene, and Miocene age crop out at several places along the margins of the Wet Mountain Valley graben (pl. 1). Only the volcanic rocks in the Wet Mountain Valley and at Deer Peak are discussed here; the rocks in the Wet Mountain Valley are at Grape Creek, Rosita, Silver Cliff, Goat Creek, Hillside, Oak Creek, and Little Cottonwood Creek. Silver Cliff, Deer Peak, and Rosita are small volcanic fields; the others are erosional remnants of a sheet of volcanic rocks derived from distant sources (Steven and Epis, 1968). Volcanic rocks also accumulated north of the Wet Mountain Valley near Howard, and many volcanic rocks, plugs, dikes, and lahars lie south of the Wet Mountain Valley in Huerfano Park along the southward extension of the graben.

\section{EOCENE SEDIMENTARY ROCKS}

Sedimentary rocks of Eocene age that predate the local volcanism are now preserved only in Echo Park (Echo Park Alluvium, same as prevolcanic arkose of Epis and Chapin, 1968, p. 59), at Goat Creek, and possibly beneath younger deposits in the Wet Mountain Valley. Clasts in these Eocene rocks were derived from low ranges having exposed Precambrian rocks north of the Arkansas River, near Bonanza, and along the general axes of the modern Sangre de Cristo Range and the Wet Mountains. We correlate these sedimentary rocks with the Huerfano Formation in the Huerfano Park area to the south, which also is a prevolcanic Eocene sedimentary rock unit (table 1 ).

\section{ECHO PARK ALLUVIUM}

The Echo Park Alluvium, which crops out at Echo Park on the north side of the Arkansas River east of its confluence with Texas Creek (pl. 1), was deposited in a 

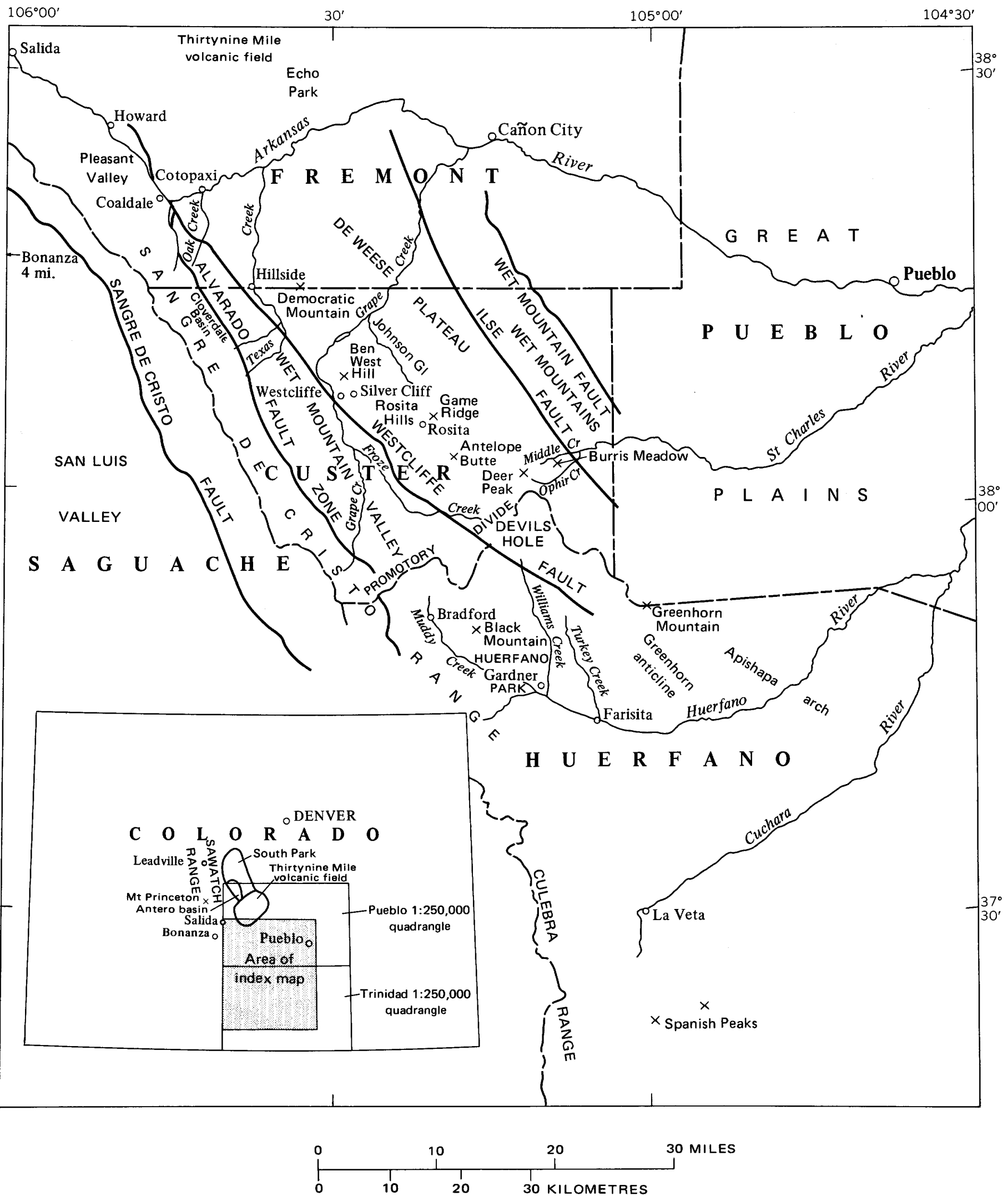

Figure 1.-Index map of area near Wet Mountain Valley, showing places and faults mentioned in text. 
south-trending stream channel that followed a graben (pl. 1). The arkose underlies the Wall Mountain Tuff (Epis and Chapin, 1974) (formerly Agate Creek Tuff or ash flow 1) of early Oligocene age (about 35 m.y., John Obradovich, written commun., 1972), which is part of the extrusive volcanic rocks shown on plate 1 . The arkose is composed of debris derived largely from granitic rocks but partly from metamorphic rocks; this debris forms irregular beds of conglomerate, sandstone, and finer grained rocks. The fine-grained rocks are in evenly

TABLE 1.-Age and events affecting Tertiary rocks in the Wet Mountain Valley and Wet Mountains

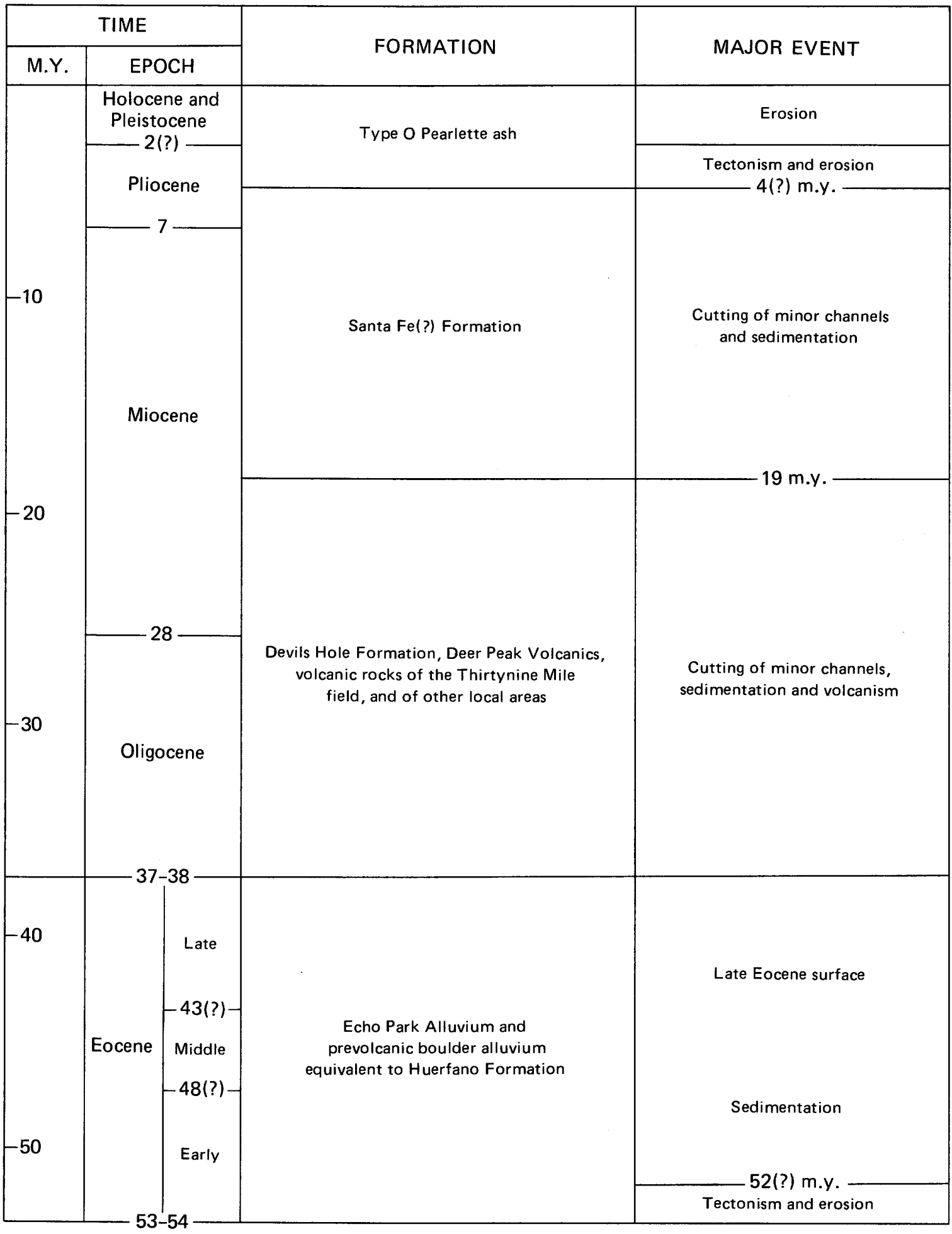


stratified beds containing carbonaceous layers with fossil leaves. MacNish (1966, p. 27) also noted quartzite boulders that he inferred were from the Ordovician Harding Sandstone. The coarse boulder alluvium of the Echo Park Alluvium probably correlates with the Farisita Conglomerate, which we consider to be a coarse facies of the Huerfano Formation. Similarly, MacNish (1966, p. 25) correlated the deposit in Echo Park with the Farisita.

The prevolcanic boulder alluvium (Echo Park?) at Goat Creek filled the lower part of a northeast-trending stream channel that extended across the preuplift site of the Sangre de Cristo Range. This deposit underlies the Wall Mountain Tuff of early Oligocene age. The alluvium at Goat Creek is composed of conglomerate containing very large boulders, cobbles, and pebbles of Precambrian granite, Cambrian(?) syenite, pre-Permian (Cambrian?) volcanic rocks, and sandstone from the Sangre de Cristo Formation. The syenite clasts apparently were derived from the Crestone Conglomerate Member of Munger (1965) of the Sangre de Cristo Formation and from other conglomerate beds in the Sangre de Cristo in the Sangre de Cristo Range. The Sangre de Cristo Formation contains numerous syenite clasts of unknown source.

\section{HUERFANO FORMATION AND RELATED ROCKS}

The Eocene beds in Huerfano Park and projecting northward under the Wet Mountain Valley consist of the Huerfano Formation, containing red sandstone and mudstone derived chiefly from sedimentary Pennsylvanian and Permian red beds in the Sangre de Cristo Range, and the Farisita Conglomerate, containing yellowish-gray coarse conglomerate and sandstone derived chiefly from granitic crystalline rocks in the Wet Mountains. These two units, totaling about 4,000 feet in thickness, appear to be laterally equivalent facies inasmuch as we have seen interlayered beds characteristic of each of the two varieties in the northern part of Huerfano Park, and similar relations have been reported by Briggs and Goddard (1956), Berner and Briggs (1958), Guyton, Hutton, and Sokolsky (1960), Robinson (1963, 1966), McCulloch (1963), Briggs (1965), and MacNish (1966).

Although the Farisita is at least in part equivalent to the Huerfano, the upper, bouldery part of the Farisita at Black Mountain (fig. 1) in Huerfano Park definitely overlies beds of Huerfano lithology but has no nearby lateral equivalent. We believe that a lateral Huerfano equivalent may well have been present once but was eroded, whereas the coarse bouldery Farisita Conglomerate on Black Mountain withstood erosion.

The Cuchara Formation consists largely of yellowishgray conglomerate, sandstone, and mudstone derived from both sedimentary and crystalline rocks and is thus an intimate mixture of the Huerfano and Farisita lithologies. Briggs and Goddard (1956, p. 42) considered the Cuchara to be a facies equivalent to the Huerfano Formation, and Robinson (1963, 1966) suggested that the name Cuchara be abandoned; we concur with the latter suggestion.

It appears, therefore, that the Eocene sedimentary rocks in the northern part of Huerfano Park and in the Wet Mountain Valley consist of three basic types: the Huerfano Formation, derived from preexisting sedimentary rocks; the Farisita Conglomerate, derived from Precambrian crystalline rocks; and the Cuchara Formation, which is an intimate mixture of the other two types. These lithologies are certainly in part, and perhaps in large part, laterally equivalent and probably would best be considered as facies of one formation rather than as three formations.

\section{OLIGOCENE AND MIOCENE INTRUSIVE AND EXTRUSIVE VOLCANIC ROCKS UNDIVIDED}

All the rocks of volcanic source are divided into seven units (pl. 1). With onset of volcanism at a number of centers along the margins and in the highlands bounding the Wet Mountain Valley, the composition of the basin fill changed abruptly from sedimentary to a mixture of lava flows, ash flows, lahars, and fluvial clastic sediments containing high proportions of volcanic debris. The Devils Hole Formation (Johnson and Wood, 1956) is a volcanic-rich sedimentary unit probably derived from early eruptions at the Rosita volcanic center. The Deer Peak Volcanics, a new formation, consists of material that spread westward and southward from a volcano along Ophir Creek east of Deer Peak. Small volcanic fields surround the Rosita and Silver Cliff centers. Andesitic lahars at Grape Creek 12 miles south of Westcliffe were derived from an unknown center possibly west of the present outcrops.

\section{DEVILS HOLE FORMATION}

The Devils Hole Formation (table 1) was named by Johnson and Wood (1956) for exposures in Devils Hole in T. 24 S., R. 70 W., Huerfano County, Colo. We here designate a reference locality for the formation in this township, along the road from Gardner to Ophir Creek, where all parts of the formation are well exposed. This apparently is where Guyton, Hutton, and Sokolsky $(1960$, p. $77-81)$ measured a section in detail and described two members of the formation. The lower member, about 850 feet thick, consists of basal conglomerate and overlying arkosic tuff; this member apparently is equivalent to the type Devils Hole Formation except for a dark volcanic mudflow (their volcanic tuffaceous conglomerate) which comprises the upper 8-35 feet of their member but which we assign to the Deer Peak Volcanics. The upper member described by Guyton, Hutton, and Sokolsky consists of mudflows 
from the Deer Peak volcano, andesite flows from local vents, volcanic-bearing alluvial gravel of late Tertiary age (Santa $\mathrm{Fe}($ ?) Formation of this report), gravels reworked from the Santa Fe(?) in Pleistocene time, and type $\mathrm{O}$ Pearlette ash. These heterogeneous deposits from many sources seem inappropriate within a single formation, and we are here limiting the name Devils Hole Formation to the pumiceous assemblage of rocks originally included in the unit by Johnson and Wood (1956).

The lower part of the Devils Hole Formation contains abundant Precambrian debris and is somewhat similar in texture to the underlying Farisita Conglomerate; the basal contact, however, is everywhere marked by the abrupt appearance of pumice and ash as clasts in the conglomerates and as tuffaceous material in finer grained rocks. At the reference locality of the Devils Hole, the lower 100 feet is a yellowish-gray to buff crossbedded conglomerate containing well-rounded cobbles and pebbles of Precambrian granitic rocks and rounded blocks of pumice and perlite in a sandy tuffaceous and arkosic matrix. In the overlying 700 feet of section, similar lenticular boulder conglomerates alternate with tuffaceous sandstones containing pebbles of Precambrian rocks and pumice. The largest pumice fragments of most beds are more than three times the diameter of the associated Precambrian clasts, apparently sorted as hydraulic equivalents. Generally, the content of pumice increases upward. The conglomeratic beds are discontinuous and lenticular, and crossbedding is well developed; the sandy and finer grained rocks are more evenly bedded. Most of these rocks are friable and poorly cemented, but the upper 150 feet of the formation contains beds of more resistant fluviatile pumice boulder conglomerate containing blocks of pumice more than 3 feet in diameter in a sandy matrix. The top of the formation at the reference locality is sharp; the pumiceous beds are overlain by a gray to brown poorly sorted volcanic conglomerate (lahar) containing andesite and latite fragments that are derived from the Deer Peak volcano and assigned to the Deer Peak Volcanics.

The Devils Hole Formation apparently had its source in the Rosita volcanic field. Pumice-bearing beds have been traced northward to a mile north of Antelope Butte, just south of Rosita, where pumice was dated at $32.1 \pm 0.9$ m.y. (million years) by Carl Hedge (written commun., 1972), and the compositions of the Devils Hole and Antelope Butte rocks are closely similar. A single ash flow dated at $27.5 \pm 2.8 \mathrm{~m} . \mathrm{y}$. by the fission track method (Charles W. Naeser, written, commun., 1973) lines a south-trending channel from Rosita nearly all the way to Devils Hole (pl. 1 , section $B-B^{\prime}$ ). Apparently the Devils Hole Formation formerly extended from the lower part of the volcanic pile at Rosita southward an unknown distance beyond Devils Hole. It was removed south of Promontory Divide by erosion during late Cenozoic time.
Just south of the Rosita volcanic field the Devils Hole Formation consists of fluvial conglomerate containing clasts of Precambrian crystalline rocks and flow-banded rhyolite, water-laid iron-stained ashy sandstone and mudstone, and mudflow debris containing boulders of Precambrian rocks, pumice, ash flow, and flow-banded rhyolite. (See description, p. 9.) Some of the pumice blocks are as large as 3 feet in diameter. The basal part of the formatin near Rosita contains local layers of flowbanded rhyolite and ash-flow tuff. The volcanic sediments presumably were derived from near Wakefield Hill and other early vents in the Rosita volcanic field; the arkosic sediments in the Devils Hole just south of Rosita probably came from Precambrian rocks in the Wet Mountains and from reworked beds correlative with the Farisita Conglomerate.

Johnson and Wood (1956, p. 719) stated that "The formation intertongues westward with red conglomeratic sandstone derived from sedimentary rocks of Pennsylvanian and Permian age." After examining these same exposures, we believe that the red sandstone actually does not intertongue with the Devils Hole; rather, it can be seen to overlie it in many places. We would correlate the red conglomeratic sandstone with the western part of the Santa Fe(?) Formation (described later in the present report), which is younger than the Devils Hole Formation.

Beds here considered to be the Devils Hole Formation were called many ages both before and after they received a formal name. These volcanic-rich beds were assigned, according to then-current usage, to the Pliocene (now early Pleistocene) by Hills (1888, p. 161); Miocene (?) by Burbank and Goddard (1937), Johnson and Wood (1956), and Johnson (1969); middle or late Tertiary by Briggs and Goddard (1956); and Pliocene by Greene and Langefeld (1956). Guyton, Hutton, and Sokolsky (1960) called them Miocene(?), Pliocene(?), and Pliocene-Pleistocene(?). They were mapped as part of the Rosita Formation but were correlated with Devils Hole Formation and called Eocene in age by Siems (1968). The Devils Hole was called late Eocene in age by McCulloch (1963), but Robinson (1966) called it Pliocene(?) on the basis of Hills' original statement (1889) about horse and camel teeth found in a volcanic ash "belonging to the Upper Pliocene." We searched diligently for fossils in the Devils Hole Formation but found none. However, we infer an Oligocene age for Devils Hole because Carl Hedge (written commun., 1972) has dated at $32.1 \pm 0.9$ m.y. a biotite-rich pumice from a bed that we correlate with the Devils Hole in the central part of the $\mathrm{E}^{1 / 2} \mathrm{SE} 1 / 4$ sec. 3, T. 23 S., R. 71 W., Custer County, Colo. The Devils Hole at the reference section underlies a bed dated as $38.2 \pm 1.5 \mathrm{~m}$.y. old by the potassium-argon method by L. I. Briggs (in McCulloch, 1963, p. 34) in the Deer Peak Volcanics, a new unit 
described in the following section of the present report. However, on the basis of the $32.1 \mathrm{~m} . y$. date, we believe that $38.2 \mathrm{~m} . \mathrm{y}$. is several million years too old.

Probable correlatives of the Devils Hole Formation have been found along Highway 96, 3.5 miles north of Rosita (pl. 1) and near the top of Greenhorn Mountain (Boyer, 1962). The outcrops north of Rosita appear to lie at the north end of the same north-south valley that trends southward through the Rosita volcanic field to Devils Hole. They consist, in ascending order, of an ironstained boulder alluvium composed largely of Precambrian rocks but containing a few volcanic fragments, an altered volcanic ash, and a thin ash-flow tuff resembling the ash flow found in the Devils Hole south of Rosita. The deposits on Greenhorn Mountain contain air-fall pumiceous tuff and water-laid gravelly ash that lies on Precambrian rocks and is overlain by andesite flows.

\section{DEER PEAK VOLCANICS}

The Deer Peak Volcanics (table 1) as here named consist of the Deer Peak stock in the southern Wet Mountains and the flows, lahars, and volcanic sediments derived from the Deer Peak volcano. Recent studies have shown these rocks to comprise a widespread assemblage of genetically related deposits that can be distinguished and mapped as a rock stratigraphic unit worthy of formational designation. They interfinger with the Devils Hole Formation near Rosita and Huerfano Park and heretofore have been mapped as parts of that unit. Andesitic lahars and volcanic sediments derived from the Deer Peak volcano were mapped as Rosita Formation by Siems $(1968$, p. 95) in his study of the Rosita volcanic field (Rosita is here called Rosita Andesite and is restricted to the original definition of Cross (1896, p. 285)); at Devils Hole, similar materials were considered as the upper part of the Devils Hole Formation by Guyton, Hutton, and Sokolsky (1960, fig. 11). Johnson (1969) mapped laharic flows here called Deer Peak Volcanics at Devils Hole as intermediate lava flows and flow breccias of Miocene(?) age.

The Deer Peak stock is a composite intrusive center located along Ophir Creek in sec. 19, T. 23 S., R. 69 W., in Custer County, Colo. It covers an area of nearly 2 square miles at altitudes ranging from 9,700 to 11,200 feet. Extrusive rocks and lahars lie north, west, south, and southeast of the stock but are preserved chiefly to the west on the west flank of Deer Peak, an 11,572-foot mountain in the south half of sec. 14, T. 23 S., R. 70 W. The type locality for the Deer Peak Volcanics is designated in secs. 22 and 27, T. 23 S., R. 70 W., near the head of the Froze Creek drainage.

The Deer Peak Volcanics extend from the stock 1 mile north to Burris Meadow, about 12 miles northwest to near Rosita, 15 miles southwest to Bradford (not shown on pl. 1), and 7 miles southeast along the crest of the Wet
Mountains. Most of the distant deposits are lahars or stream-laid materials that flowed from a volcanic vent above the present stock down valleys in the Precambrian bedrock. The lahars completely filled some of these valleys, partially filled others, and are interspersed with lava flows on the flanks of the volcano. Andesite, latite, and rhyodacite flows from a near-source facies were observed no farther than 4 miles from the former vent. Most of the lahars and lava flows overlie Precambrian rocks; locally they rest on the lower Oligocene boulder alluvium. To the west, the lahars interfinger completely with pumiceous (rhyolitic) lahars of the Devils Hole Formation. In the Wet Mountain Valley, the formation is overlain by alluvial basin-fill deposits of Miocene and Pliocene age designated as the Santa Fe(?) Formation.

Two general stratigraphic sections of the extrusive and laharic rocks from the Deer Peak volcano indicate that andesitic and latitic lavas predominate and that the andesitic rocks make up the greatest volume of ejecta. The volcanics appear to be more than 1,500 feet thick locally, as in the type section in secs. 22 and 27, T. $23 \mathrm{~S}$., R. $70 \mathrm{~W}$., but poor exposures do not permit accurate measurements. In addition, a reference section measured in sec. 4, T. $23 \mathrm{~S}$., R. $70 \mathrm{~W}$., is included for comparison. In both, the laharic deposits include much Precambrian detritus low in the section and lesser amounts higher up, indicating that the Precambrian bedrock beneath the volcanic carapace was being progressively covered by volcanic rocks.

Type section of the Deer Peak Volcanics, secs. 22 and 27, T. 23 S., R. $70 \mathrm{~W}$ [Measured by R. B. Taylor in 1968]

Thickness

(feet)

13. Latite porphyry flow, reddish-brown to light-red; contains breccia fragments and is scoriaceous and crystal rich in upper part, massive but porphyritic in lower part; phenocrysts of plagioclase to $1 \mathrm{~cm}$ and smaller sanidine, hornblende, pyroxene, and biotite; altered

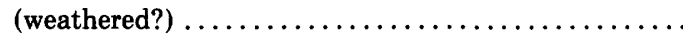

12. Latite porphyry flow, dark- to light-gray; aphanitic groundmass, phenocrysts of plagioclase to $1 \mathrm{~cm}$ and smaller hornblende and biotite ...............

11. Lahar, largely covered; contains abundant cobbles of andesite and latite $\ldots \ldots \ldots \ldots \ldots \ldots \ldots \ldots \ldots \ldots \ldots \ldots \ldots \ldots$

10. Latite porphyry flow, medium- to light-gray; aphanitic groundmass, phenocrysts of plagioclase to $1 \mathrm{~cm}$ and smaller biotite, hornblende, and sanidine(?) .......

9. Lahar; interval largely covered; float is mixed andesite and

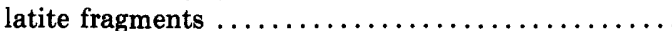

8. Quartz latite porphyry flow, light-gray; aphanitic groundmass, phenocrysts of plagioclase to $5 \mathrm{~mm}$ and smaller biotite, hornblende, sanidine(?), and sparse gray quartz; possibly a tuff $\ldots \ldots \ldots \ldots \ldots \ldots \ldots \ldots \ldots$

7. Lahar; interval largely covered; andesite fragments abundant, rounded boulders and cobbles mostly of andesite and latite but containing Precambrian gneiss and

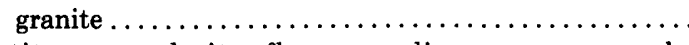

6. Latite or andesite flows, medium-gray, sparsely porphyritic; interval includes at least two, possibly 
Type section of the Deer Peak Volcanics-Continued Thickness (feet)

four, flows; upper unit massive and dense, lower units scoriaceous to massive; phenocrysts to $3 \mathrm{~mm}$ are plagioclase, pyroxene, and some biotite and

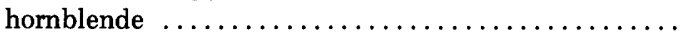

5. Lahar; coarser in upper part; contains andesite fragments in andesitic matrix; lower part more sandy, with sparse Precambrian gneiss fragments; boulders to 3 -ft diameter ..............................

4. Latite or andesite flow, reddish-brown to brownish-gray; aphanitic groundmass, phenocrysts of plagioclase, hornblende, and sparse biotite; probably two flows, upper is lighter in color and has more biotite, lower has more prominent plagioclase phenocrysts and purplish

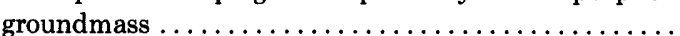

3. Lahar; boulders and smaller fragments in sandy mud ("concrete") matrix; andesite and latite fragments intermixed with abundant Precambrian gneiss and

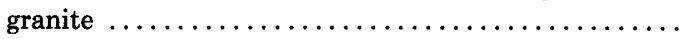

2 . Andesite porphyry flow, medium-gray; aphanitic groundmass, abundant phenocrysts of hornblende and plagioclase to $6 \mathrm{~mm}$, less abundant pyroxene and biotite; massive near base, scoriaceous to brecciated at top .............................. 0-200

1. Lahar; boulders and smaller fragments, to 4 -ft dimension, in sandy mud ("concrete") matrix; contains both volcanics and Precambrian gneiss ............. $0-350$

Total .......................

The principal part of the Deer Peak stock is made up of rhyodacite porphyry containing phenocrysts of hornblende and plagioclase set in a fine-grained to aphanitic matrix. The rock is light gray and weathers to shades of tan and brown. Darker andesitic(?) rocks form dikes and irregular masses that cut the southwestern part of the body. A late vent filling of breccia and pitchstone, covering about an eighth of a square mile, cuts the stock at its southeastern margin; this mass consists of volcanic breccia and pitchstone with a chilled pitchstone margin. The pitchstone is brown to greenish brown and contains clay-altered phenocrysts of plagioclase and sanidine. The interior breccias are chaotic mixtures of andesite and latite porphyry blocks and are irregularly altered to clay, sericite, and other minerals. This breccia appears to represent the last material filling a peripheral vent of the Deer Peak volcano. A hydrothermally altered breccia pipe of limited size in the northwest part of the stock is inferred from material found on old mine workings just west of the Ophir Creek road. Quartz, sericite, and pyrite veins permeate brecciated stock rock. The stock is interpreted to represent the main conduit supplying the Deer Peak volcano; now-exposed levels, however, are below the extrusive part of the cone where the stock is bounded by steep Precambrian rock walls.

Projecting the Deer Peak flows updip toward the stock center suggests that the volcano once attained a height equivalent to a present altitude of at least 13,500 feet.
Reference section of the Deer Peak Volcanics, sec. 4, T. 23 S., R. $70 \mathrm{~W}$

[Measured by R. B. Taylor in 1968]

Thickness

(feet)

9. Andesite flow, dark- to medium-gray; aphanitic granular groundmass, very sparse plagioclase and pyroxene phenocrysts to $2 \mathrm{~mm} . \ldots \ldots \ldots \ldots \ldots \ldots \ldots \ldots \ldots$.

8. Laharic breccia; nonsorted gray, brown, and purplish-gray andesite and porphyritic andesite boulders and smaller fragments in andesitic matrix; lacks obvious bedding; sparse Precambrian debris .....................

7. Andesite flow, light-reddish-brown to almost brick-red; scoriaceous top grades downward to aphanitic porphyry; altered pyroxene (?) phenocrysts in massive groundmass, plagioclase and pyroxene phenocrysts to $3 \mathrm{~mm}$ in scoria

6. Mudflow; nonsorted boulders, cobbles, and pebbles in lightgray sandy mud matrix; andesite and Precambrian gneiss and granite varieties abundant $\ldots \ldots \ldots \ldots \ldots \ldots \ldots$

5. Latite flow, medium- to light-gray, scoriaceous; gray aphanitic groundmass, sparse 1- to 2-mm phenocrysts of plagioclase, biotite, hornblende, and pyroxene ........

4. Rhyolite tuff, light-tan to gray, altered-appearing, porphyritic; possibly a flow; phenocrysts of sanidine, biotite, and plagioclase(?) set in tan finely crystalline groundmass with many irregular gas cavities .........

3. Pumiceous mudflow; white clay-altered rhyolite and pumice fragments to boulder size in light-pinkish-tan ashy mud; no bedding seen ....................

2. Algal limestone (breccia), tan, banded; contains boulders and smaller fragments of Precambrian granite and gneiss and very sparse fragments of andesite $\ldots \ldots \ldots \ldots \ldots$.

1. Mudflow or lahar; boulders and smaller fragments of andesite and Precambrian rocks in sandy mud matrix, no sorting or bedding; channel fill in valley in Precambrian rock, inferred thickness is a maximum ..............

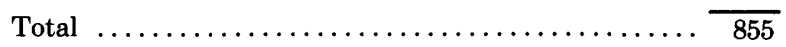

Thus, to expose the present outcrop in the walls of a steep-sided mountain valley, 2,000-4,000 feet of rock at the stock center must have been removed by erosion.

The Deer Peak Volcanics are Oligocene in age. An age of $38.2 \pm 1.5$ m.y. was obtained by L. I. Briggs (in McCulloch, 1963, p. 34) by the potassium-argon method on biotite in an andesite boulder from a lahar in the Deer Peak Volcanics in sec. 34, T. 23 S., R. 70 W., Huerfano County, Colo., but we believe that this date probably is several million years too old. This lahar is the lowest unit (bed 1) in the type section, and although it cannot be placed precisely in the time range of extrusive activity, it must be very early. Erosion has removed the youngest parts of the Deer Peak volcano, and no isotopic dates from the stock are available. The Deer Peak volcano probably erupted during an appreciable part of the Oligocene lifespan of the adjoining Rosita volcanic field.

\section{VOLCANIC ROCKS AT GRAPE CREEK}

A small deposit of lahar chiefly made up of andesite fragments crops out at Grape Creek in T. 24 S., R. 72 W. A sample of the andesite collected by R. D. MacNish was dated by L. I. Briggs (Volckmann, 1965, p. 71) at 41.2 $\pm 1.2 \mathrm{~m} . \mathrm{y}$. We suspect that this date also is too old 
and probably should be Oligocene. According to Volckmann the rock is dark brown to maroon, vesicular in places, and somewhat brecciated. The lahar lies along the Alvarado fault zone at the east margin of the Sangre de Cristo Range and dips eastward toward the Wet Mountain Valley (MacNish, 1966). The source of the lahar is unknown, but we infer that it lies to the west and that the lahar was deposited along a preuplift channel across the Sangre de Cristo Range.

\section{VOLCANIC ROCKS AT ROSITA}

The Rosita area has been studied by Cross $(1890,1896)$ and Siems (1968) and is currently being studied by William N. Sharp, U.S. Geological Survey. An early volcanic center around Rosita, interpreted by Siems (1967) as an incompletely developed resurgent cauldron, is ringed by rhyolitic domes and flows and is partly occupied by subvolcanic intrusive rocks. The major volcanic deposits are described in the following sequence interpreted by us as youngest to oldest:

Rhyolite-light-gray rhyolite plugs at Mount Tyndall, Wilmer Gulch, Antrim Lode, and Antelope Butte. Dated by Carl Hedge (written commun., 1972) at $26.3 \pm 0.7$ m.y. for Antrim Lode and at $27.3 \pm 0.8$ m.y. for Antelope Butte.

Trachyte-light-purplish-gray porphyritic trachyte in stocks and dikes; $1 / 2$-inch phenocrysts of plagioclase and smaller biotite and sanidine crystals set in groundmass of cryptocrystalline feldspar. Dated by L. I. Briggs at $33.2 \pm 0.9$ m.y. (MacNish, 1966) by potassium-argon method on a sample from Game Ridge; date probably is too old.

Pringle Latite (Cross, 1890, p. 276) - gray porphyritic biotite latite in stocks and dikes and in flows outside the cauldron; plagioclase, sanidine, biotite, and pyroxene phenocrysts in a fine-grained groundmass.

Bunker trachyandesite (Cross, 1890, p. 272)-dark-yellowish-gray porphyritic fine-grained syenodiorite to gray porphyritic trachyandesite; plagioclase and biotite phenocrysts abundant, lesser amounts of hornblende or pyroxene in groundmass that varies from fine grained to aphanitic; forms stocks, dikes, and flows.

Rhyolite-light-gray, greenish-gray rhyolite and rhyolite porphyry; flow banded, spherulitic, glassy, or perlitic; phenocrysts of sanidine, quartz, and local plagioclase and biotite.

Rhyodacite-gray fine-grained porphyritic rhyodacite; plagioclase, biotite, and hornblende phenocrysts set in a felted groundmass; forms plug.

Rosita Andesite (Cross, 1896, p. 285) and its vent equivalent Bassick Agglomera (Cross, 1896, p. 307)-drab-gray, brownish- or greenish-gray porphyritic andesite and trachyandesite; phenocrysts of plagioclase, hornblende, and pyroxene in an aphanitic groundmass; includes medium to coarse andesite breccia flows and lahars; Bassick Agglomerate is considered by us a coarse breccia facies of the Rosita in the northern part of the cauldron; Rosita consists of andesitic flows, intrusive and extrusive breccias, and laharic deposits.

Equivalents of the Devils Hole Formation-beds considered by us to be correlative with the Devils Hole Formation contain the following units, some of which intertongue with Deer Peak Volcanics:

Rhyolite-reddish-brown to gray flow-banded porphyritic rhyolite. Boulder alluvium-rounded boulders and smaller clasts of flowbanded rhyolite and Precambrian granite and gneiss.

Ash-sand-sized clastic deposit of volcanic ash; contains biotite, quartz, sanidine, and plagioclase crystals in matrix of reddish- brown clay derived from devitrified ash shards.

Ash-flow tuff-pink to yellowish-gray crystal-rich tuff; contains biotite, chatoyant sanidine, and sparse fragments of volcanic and Precambrian rocks. Dated by fission-track method by Charles W. Naeser (written commun., 1973) at $27.5 \pm 2.8$ m.y.

Volcanic glass-greenish-gray locally devitrified glass.

Tuff-air-fall and water-laid volcanic ash.

Pumiceous lahar-boulders of Precambrian rocks and flowbanded rhyolite in lahar chiefly made up of ash and pumice. A biotite-rich pumice bed was dated by Carl Hedge (written commun., 1972) at $32.1 \pm 0.9 \mathrm{~m} . \mathrm{y}$. from the center of the $\mathrm{E}^{1 / 2} \mathrm{SE} 1 / 4$ sec. 3 , T. 23 S., R. 71 W., Custer County, Colo.

\section{VOLCANIC ROCKS NEAR SILVER CLIFF}

The Silver Cliff volcanic area was studied first by Cross (1896) and later by Siems (1968) and is currently being investigated by William N. Sharp, U.S. Geological Survey. The thickest accumulation of volcanic rocks lies in a volcanic subsidence area west of Round Mountain. According to Sharp (written commun., 1969), low residual gravity anomalies indicate several thousand feet of relatively light density volcanic debris in a troughshaped graben bounded by walls of Precambrian gneiss. Mine workings show that the upper part of this fill is made up of flows, stratified tuff, breccia, and water-laid debris. This material is capped at the present surface by flows of flow-layered porphyritic rhyolite and spherulitic rhyolite with thick basal layers of black obsidian. Unpublished gravity data of the U.S. Geological Survey suggest a second local volcanic center marked by porphyritic quartz latite intrusions near Ben West Hill. Volcanic activity at Silver Cliff overlapped that at Rosita, and Sharp has mapped flows from Rosita within the subsided trough at Silver Cliff.

\section{WATER-LAID ASH AT JOHNSON GULCH}

A deposit of white water-laid ash crops out between Johnson and Fourmile Gulches in and near sec. 26, T. 21 S., R. 72 W., Custer County, Colo., about 5 miles northeast of Westcliffe. Beds of clay-sized ash in the deposit generally are thinly laminated and are cyclically banded with thicker layers of silt- or sand-sized ash. Fissility is so well developed in the fine-grained layers that the material closely resembles the "lake shales" in the Florissant Lake Beds. Beds of coarse sand-sized ash are only crudely layered. The thickness of the ash unit probably exceeds 200 feet. A hole drilled in the NW1/4 sec. 35 , T. 21 S., R. $72 \mathrm{~W}$., many years ago penetrated 167 feet of water-laid ash without reaching the base.

The ash is overlain by boulder alluvium containing large clasts of Precambrian rocks, ash-flow tuff, and other volcanic rocks. A small lentil of algal limestone is interlayered with the boulder alluvium in the $\mathrm{SW}^{1 / 4} \mathrm{sec}$. 26, T. 21 S., R. 72 W. A sample was examined for us by J. Harlan Johnson, Professor Emeritus of Geology at Colorado School of Mines, who reported in June 1968 (written commun.) that the algal limestone was "Un- 
questionably a stromatolithic deposit, formed by the presence and possibly biochemical activity of blue-green algae." The material was too poorly preserved to be datable.

Despite careful search, no fossil leaves, mollusks, or bones were found. The age of the water-laid ash is suspected to be early Oligocene, and we believe it to be about the same age as the Florissant Lake Beds, Antero Formation of Johnson (1937), and buried water-laid ash reported by William N. Sharp of the U.S. Geological Survey (oral commun., 1969) at the base of the volcanic pile in the Silver Cliff volcanic field.

\section{VOLCANICS OF THE THIRTYNINE MILE VOLCANIC FIELD}

Sequences of volcanic rocks at Goat Creek, Hillside, Oak Creek, and Little Cottonwood Creek and isolated patches of ash-flow tuff on the De Weese Plateau contain volcanic rocks typical of those in the Thirtynine Mile volcanic field (fig. 1) (Steven and Epis, 1968, p. 253). Parts of these sequences are derived from the distant and little-known sources that supplied the ash flows of the Thirtynine Mile field, but other parts came from local vents interpreted as structurally localized along major faults bounding the Wet Mountain Valley graben. The volcanic rocks at the north end of the Wet Mountain Valley probably were derived from the west and were deposited in east-trending channels that extended across the Sangre de Cristo Range area before uplift. The greatest thicknesses probably were deposited in a developing structural and topographic trough along the Wet Mountain Valley, and lesser thicknesses were deposited on the plateau to the east (pl. 1, sec. $A-A^{\prime}$ ).

\section{GOAT CREEK}

A sequence of volcanic rocks about 3,000 feet thick dips about $30^{\circ}-45^{\circ} \mathrm{NE}$. into the west edge of the Wet Mountain Valley graben 4 miles south of Hillside in the southeastern part of T. 46 N., R. 12 E. (pl. 1, sec. $A-A^{\prime}$ ). Three ash flows in the sequence are correlated with the Wall Mountain Tuff (ash flow 1 of Epis and Chapin, 1968, p. 67) and with the Thorn Ranch and Gribbles Park Tuffs (ash flows 6 and 7) of the Thirtynine Mile volcanic field (Chapin and Epis, 1964); these are interlayered with flows and laharic material possibly derived from a volcano related to the Rito Alto stock at Cloverdale Basin 6 miles to the west or from local vents. The sequence is overlain by the Santa Fe(?) Formation and overlies the Echo Park(?) Alluvium, which is a prevolcanic arkosic boulder alluvium containing Cambrian(?) syenite and Precambrian granite. From top to bottom the section is as follows:

Santa Fe(?) Formation.

Biotite latite-light-brownish-gray porphyritic latite flow; fresh sanidine and biotite phenocrysts set in aphanitic groundmass; probable local source.
Hornblende-pyroxene andesite-gray porphyritic andesite flow; phenocrysts of plagioclase, hornblende, and pyroxene in glassy groundmass; source unknown but probably local.

Pyroxene andesite-gray dense andesite flow; trachytoid flow-lineated groundmass; source unknown but probably local.

Gribbles Park Tuff-pinkish-gray to brown rhyolitic ash-flow tuff; phenocrysts of bronze biotite, chatoyant sanidine, and lithic fragments in glass shard matrix; contains a medial lens of white pumiceous lahar having pumice fragments to $8 \mathrm{in}$. which contain phenocrysts of smoky quartz and sanidine and a sand-sized ash matrix; source unknown; interlayered pumice mudflow from unknown source is possibly unrelated to ash-flow tuff.

Lahar-dark grayish-brown clasts of andesite and flow-banded rhyolite; locally derived. This and two underlying units are shown as lahar in section $A-A^{\prime}$ (pl. 1).

Andesite-dark-brownish-gray fine-grained andesite flow; contains green opal; source probably local.

Lahar-light-gray tuffaceous debris with pumice blocks; source and flow direction uncertain.

Thorn Ranch Tuff-yellowish-gray ash-flow tuff; contains purplishgray lithic fragments; source unknown.

Boulder alluvium, ash, and pumiceous mudflow.

Biotite latite-pinkish-gray porphyritic biotite latite flow; phenocrysts of plagioclase and biotite set in fine-grained crystalline groundmass; probably from Hillside.

Mudflow-gray volcanic-rich mudflow.

Wall Mountain Tuff--brownish-gray to reddish-brown ash-flow tuff containing glassy fresh sanidine, altered plagioclase, and bronze biotite; moderately to densely welded and partly devitrified, source unknown. Tuff in Thirtynine Mile volcanic field was dated by John Obradovich (written commun., 1972) at about 35 m.y.

Echo Park(?) Alluvium-reddish-brown bouldery alluvium containing granite and syenite.

\section{HILLSIDE}

An area of about 8 square miles east of Hillside is underlain by extrusive and detrital volcanic rocks. East Gulch, Thorn Ranch, and Gribbles Park Tuffs of the Thirtynine Mile volcanic field have been recognized, together with andesitic and latitic rocks from a local vent. The volcanic sequence at Hillside lies on Precambrian gneiss and granite and dips $5^{\circ}-20^{\circ} \mathrm{W}$. into the Wet Mountain Valley graben (pl. 1, sec. $A-A^{\prime}$ ). The sequence as now preserved contains more than 1,000 feet of volcanic rocks; its eroded top is covered by the Santa $\mathrm{Fe}($ ?) Formation. From youngest to oldest the volcanic rocks at Hillside are as follows:

Santa Fe(?) Formation.

Hornblende-pyroxene andesite-dark-pinkish-gray porphyritic flow; phenocrysts of plagioclase, hornblende, and pyroxene set in aphanitic trachytoid groundmass; probable local source.

Andesite-gray dense flow; pilotaxitic groundmass; probable local source.

Biotite latite-dark-gray porphyritic flow; plagioclase, biotite, pyroxene, and hornblende phenocrysts set in groundmass that varies from glassy to aphanitic crystalline: local vent.

Water-laid ash-light-gray well-stratified ash; contains silt, fine sand, and glass shards.

Lahar-yellowish-gray pumiceous lahar; poorly sorted and not visibly bedded; source unknown, but in part contains reworked debris from ash flow below.

Gribbles Park Tuff-gray, pinkish-gray, to brown welded and glassy to unwelded ash-flow tuff; phenocrysts of bronze biotite and 
chatoyant sanidine; source unknown. The Gribbles Park ash flow in the Thirtynine Mile volcanic field was dated by John Obradovich (written commun., 1972) at $28.6 \pm 0.6$ and $29.5 \pm 0.7$ m.y.

Gravel-volcanic-rich gravel containing fragments of Wall Mountain, Thorn Ranch, and Gribbles Park Tuffs, andesite, fine-grained syenite, and Precambrian rocks; apparently in part older and in part contemporaneous with Gribbles Park Tuff. Not shown in section $A-A^{\prime}$.

Air-fall pumice and pumiceous lahar-yellowish-gray deposits; source uncertain. Not shown in section $A-A^{\prime}$.

Bouldery colluvium-ill-sorted boulder-bearing deposit chiefly composed of granitic rocks similar to material on De Weese Plateau; on north side of volcanics this interval is made up chiefly of a thin layer of cobbles of olivine-pyroxene basalt.

Thorn Ranch Tuff-yellowish-gray ash-flow tuff; contains inconspicuous sanidine phenocrysts and purplish lithic fragments; source unknown.

Tuffaceous lahar-at north edge of area chiefly composed of biotite latite.

East Gulch Tuff-white to yellowish-gray ash-flow tuff chiefly made up of Precambrian and volcanic lithic fragments and pumice lumps in a matrix of glass shards; source unknown.

Water-laid tuff and pumiceous lahar-water-laid well-bedded tuff, airfall ash beds, and ill-sorted pumiceous laharic deposits; unit crops out best along and south of Reed Gulch, where it resembles lithologically the Antero Formation of the Thirtynine Mile volcanic field, a unit which also lies below the East Gulch Tuff.

Biotite latite-gray porphyritic latite flow or flows; phenocrysts of plagioclase, sanidine, and biotite in aphanitic or glassy groundmass; same rock occurs in dikes; local source.

Siltstone-light-brown muddy siltstone; prominent altered biotite flakes, reddened clays, some nontronite; volcanic source unknown; lies on Precambrian gneiss and granite along Texas Creek. Not shown in section $A-A^{\prime}$.

North and east of Hillside on the northern part of the De Weese Plateau, small remnants (pl. 1) of ash-flow tuff rest on Precambrian bedrock or on thin alluvial gravels that lie directly on the bedrock. These remnants are correlated with the Gribbles Park Tuff of the Thirtynine Mile volcanic field because of their color, mineralogic composition, texture, and varieties of included lithic fragments. Preservation of these outcrops suggests that this ash flow once extended over most of the area from Hillside eastward to Canon City and northward into the Thirtynine Mile volcanic field on the prevolcanic surface, as described by Chapin and Epis (1964) and Epis and Chapin (1968).

\section{OAK CREEK}

The sequence of volcanic rocks that crops out along the north flank of the Wet Mountain Valley graben at Oak Creek, 3-4 miles south of Cotopaxi, is more than 800 feet thick. The Thorn Ranch and Gribbles Park Tuffs of the Thirtynine Mile volcanic field were identified, together with other volcanic units of uncertain source. The rocks are gently dipping or nearly flat lying, but are segmented by the faulting which formed the graben. The volcanics are covered by the Santa Fe(?) Formation and lie on Precambrian gneiss and granite. The volcanic sequence is as follows, from youngest to oldest: Santa Fe(?) Formation.
Lahar-chiefly fragments of porphyritic andesite containing many phenocrysts of hornblende, pyroxene, and plagioclase in aphanitic or trachytoid groundmass; source in Thirtynine Mile volcanic field.

Hornblende andesite-olive-gray porphyritic andesite flow; phenocrysts of hormblende and plagioclase in fine-grained to aphanitic groundmass; source unknown.

Andesite-olive-gray dense andesite flow; source unknown.

Gribbles Park Tuff-gray ash-flow tuff; contains abundant and conspicuous chatoyant sanidine phenocrysts; source unknown.

Thorn Ranch Tuff-yellowish-gray ash-flow tuff; contains purplishgray lithic fragments; source unknown.

Ash-yellowish-green devitrified and clay-altered volcanic ash; questionably equivalent to Antero Formation of Thirtynine Mile volcanic field.

Echo Park(?) Alluvium-prevolcanic boulder alluvium preserved in narrow graben.

\section{LITTLE COTTONWOOD CREEK}

A volcanic sequence more than 850 feet thick along Little Cottonwood Creek in T. 47 N., R. 11 E., about 4 miles southwest of Cotopaxi, fills the narrowed northwest end of the Wet Mountain Valley graben in a zone extensively broken and downdropped by branches of the Pleasant Valley fault. The Wall Mountain, Thorn Ranch, and Gribbles Park Tuffs were recognized, together with other units of unknown but possibly local sources. The volcanics lie on Precambrian gneiss and granite and are overlain by the Santa $\mathrm{Fe}($ ?) Formation. From youngest to oldest, the sequence is as follows:

Santa $\mathrm{Fe}($ ?) Formation.

Lahar-chiefly fragments of porphyritic hornblende-pyroxene andesite; volcanic rocks resemble andesite of Waugh Mountain in Thirtynine Mile volcanic field.

Gribbles Park Tuff-gray ash-flow tuff containing bronze biotite and abundant chatoyant sanidine; source unknown.

Thorn Ranch Tuff-yellowish-gray ash-flow tuff; contains phenocrysts of sanidine and biotite and fragments of pumice and purplish-gray volcanic rock with glass shard matrix; source unknown.

Ash-white or light-gray water-laid tuff; contains sanidine, biotite, and pumice and andesite fragments; possibly equivalent to Antero formation.

Biotite latite-gray latite porphyry flow; contains plagioclase and biotite phenocrysts in aphanitic groundmass; probable local source.

Lahar-andesite and latite cobbles; lacks flow-banded rhyolite clasts; source unknown.

Lahar-andesite, latite, and flow-banded rhyolite volcanic rocks together with Precambrian granite boulders to 4 feet in diameter; source uncertain.

Lahar-boulders of Precambrian granite and scarce flow-banded rhyolite to 4 feet maximum diameter; source uncertain.

Wall Mountain Tuff-pinkish-gray to brown ash-flow tuff; contains abundant sanidine and biotite crystals and lithic fragments in glass shard matrix; source unknown.

\section{MIDDLE AND UPPER TERTIARY SANTA FE(?) FORMATION}

The uppermost Tertiary deposit in the Wet Mountain Valley is a salmon-pink basin-fill alluvium that we correlate with the Santa Fe Group of New Mexico. The Santa $\mathrm{Fe}($ ?) Formation crops out here and there from south of Promontory Divide northward nearly 35 miles to Oak Creek, 3 miles south of Cotopaxi. It extends eastward 
from the east flank of the Sangre de Cristo Range, where it emerges from a cover of glacial drift, to the north edge of the Rosita Hills in sec. 7, T. 22 S., R. 71 W., and covers a part of the De Weese Plateau east of Democratic Mountain. Nearly everywhere the beds are flat lying. Although the deposit is deeply dissected, cobbles and boulders pave the slopes and prevent the development of badlands that might offer a chance of finding fossils.

The Santa $\mathrm{Fe}($ ?) is composed of irregularly stratified stream-deposited fine to coarse muddy sand, pebbles, cobbles, and boulders. In the southern part of the area north of Promontory Divide, caliche cements many beds as much as several feet thick to the consistency of concrete or soft mortar; caliche is less common to the north. The lithology of the rock fragments varies greatly in different parts of the basin of deposition. In the southeast, near Devils Hole and Rosita, most of the coarse clasts are andesitic or latitic lavas, but Precambrian gneiss, granite, and aplite are also present; along the east flank of the Sangre de Cristo Range, most clasts are Pennsylvanian and Permian sandstone and siltstone; northwest of Hillside, many fragments are tonalite or porphyritic granite derived from the Rito Alto stock at Cloverdale Basin. The layers in the formation are rudely stratified, and pebble beds are discontinuous.

Near Goat Creek, the basal part of the Santa Fe(?) contains several hundred feet of boulder gravel first described by MacNish (1966). Both the gravel beds and the underlying Gribbles Park Tuff dip easterly toward the Wet Mountain Valley graben at angles of about $45^{\circ}$. The similar inclinations suggest that the gravel and ash flow are equally deformed and hence that major uplift of the Sangre de Cristo Range and part of the downfaulting of the graben took place not only after deposition of the ash flow (about 29 m.y., John Obradovich, written commun., 1972) but also after deposition of the lower gravel of the Santa Fe(?).

The gravel contains fragments of Precambrian granitic rocks, Cambrian (?) syenite, Mississippian Leadville Limestone, Jurassic Ralston Creek and Morrison Formations, and Cretaceous Dakota Sandstone. Possible sources for many of the clasts can be interpreted. Nearby sources are known for the Leadville Limestone to the north along the west flank of the Wet Mountain Valley. The Precambrian rocks could have been derived either from fault slivers on the west side of the valley or from the plateau to the east. The Cambrian(?) syenite most closely resembles the rock from the Sangre de Cristo Formation and the Crestone Conglomerate Member of that formation in the Sangre de Cristo Range. The closest known Ralston Creek, Morrison, and Dakota beds are in the Canon City area, but inasmuch as the Sangre de Cristo Range apparently arose after the deposition of these gravels, a western source is more probable.
The thickness of the Santa Fe(?) is poorly known but appears to exceed 1,200 feet. In the southern part of the outcrop area, the base is exposed, but most of the upper part has been removed by erosion; near Westcliffe in the central part of the area, the base is not exposed, and the top is eroded; to the north the beds are warped by faulting near Goat Creek, covered by outwash, and extensively dissected. In a water test hole drilled in the $\mathrm{NW}^{1 / 4} \mathrm{NE}^{1 / 4} \mathrm{NE}^{1 / 4}$ sec. 6, T. 23 S., R. 72 W., Lloyd A. Hershey (written commun., 1971) logged nearly 1,200 feet of beds which he identified as Santa $\mathrm{Fe}(?)$. As preserved, and probably as deposited, the formation is thicker in the Wet Mountain Valley than on the De Weese Plateau, and in the valley it probably thickened to the south. The Santa Fe(?) overlies the Devils Hole Formation, the Deer Peak Volcanics, and Miocene and Oligocene volcanic rocks near Hillside and Goat Creek.

Interpretations of the stratigraphic relations and age of the unit we call Santa $\mathrm{Fe}($ ?) have ranged widely over the years, and some rocks have been grouped in the Santa $\mathrm{Fe}($ ?) that we believe should not be included. The history of these interpretations is briefly reviewed here to show the relationships of the Santa Fe(?), Devils Hole Formation, and type O Pearlette ash.

In 1888, Hills described 700-800 feet of beds near Promontory Divide consisting in the lower half of loosely aggregated coarse conglomerates and sandstones and in the upper half of fawn or buff compact locally sandy marls. A basal conglomerate that he described as containing a large amount of eruptive material probably represents the beds now being called Devils Hole Formation. The upper part of Hills' unit certainly includes the beds we now call Santa $\mathrm{Fe}($ ?). To all these beds, Hills assigned a Pliocene age; the word "Pliocene" in 1888 was equivalent in part to "older Pleistocene" of today's usage.

In 1889, Hills described deposits of volcanic ash that "probably belong at the base of the series of marls and conglomerates" on Promontory Divide. Apparently Hills believed this ash to be in beds we call Devils Hole Formation. We searched, as did McCulloch (1963), for such a volcanic ash and found it only in Quaternary pediment deposits. The ash is a Pearlette family ash bed of Quaternary age. Teeth and bones of Camelops and Equus "that probably belong to the Upper Pliocene" were excavated from the ash by J. Milligan, a skilled amateur collector hired by Hills. Thus, Hills considered that he had confirmed his (1888) Pliocene (early Pleistocene) age of the beds we call Devils Hole and Santa Fe(?). The assignment of probable Quaternary volcanic ash to the older beds at Promontory Divide was repeated by Cragin (1892, p. 257), a miscorrelation with the beds we call Devils Hole and Santa Fe(?) that was continued for many years.

Guyton, Hutton, and Sokolsky (1960) included the 
beds we call Santa Fe(?) in the upper part of their Devils Hole Formation, dated as young as Pleistocene(?) (p. 11, fig. 2) and as old as Miocene(?) (map explanation). McCulloch (1963, p. 34) determined that the volcanic ash was a Pearlette-like ash in pediment gravels on Quaternary terraces south of Promontory Divide. Siems (1967, p. 90) assigned the beds we call Santa Fe(?) to late Tertiary or Quaternary.

In 1966, MacNish (p. 58-66) proposed the name "Caldwell Gulch Formation" for the Santa Fe(?). If our correlation of these beds is correct, however, the name "Santa Fe" would have priority over his new name. Johnson (1969) mapped the beds we call Santa Fe(?) as alluvial gravels and sands of Miocene, Pliocene, and Pleistocene age.

No identifiable fossils or volcanic ash beds have been found in the Santa Fe(?) although a few scraps of bone were found at a gravel pit in the NE $1 / 4 \mathrm{SW}^{1 / 4}$ sec. $17, \mathrm{~T}$. 47 N., R. 12 E., Fremont County, Colo. We attribute the lack of preservation of volcanic ash and fossils to the action of turbulent streams during deposition of the coarse alluvium. In addition, good exposures are lacking; the formation is extensively grassed over, and the largest bare outcrop covers only about 1 acre.

We assign a Miocene and Pliocene age to the Santa $\mathrm{Fe}(?)$ on the basis of its texture, color, and stratigraphic and geomorphic position. The upper part, however, contains unmapped beds reworked in Quaternary time. Lithologically it most closely resembles the Wagontongue and Trump Formations of Stark and others (1949, p. 68-72). The age probably is the same as that of the Dry Union and Ogallala Formations.

\section{PLEISTOCENE PEARLETTE ASH}

The ages assigned to beds we correlate with the Devils Hole Formation and the Santa Fe(?) were for many years based on fossil vertebrates from a volcanic ash bed of uncertain position, as cited by Hills (1889). The locality of the ash and bones as given by Hills was "between Muddy and Turkey Creeks." Hay (1924, p. 166) quoted Hills as stating that the specimens were collected near Gardner "in volcanic ash beds west of Williams Creek. [Probably in T. 25 S., R. 70 W.] These beds are only about 0.25 mile wide and extend westward from the creek 2 or 3 miles." The fossils had been identified by Cragin (1892) as a llama, Auchenia huerfanensis Cragin, and a horse, Equus sp. The llama was reexamined and figured by Hay (1913), who concluded that it should be called Camelops huerfanensis (Cragin) of Pleistocene age-the same age as originally intended by Hills (1889) in his use of the word "Pliocene." These specimens were considered lost (for instance, by Robinson, 1966, p. 17) until G. Edward Lewis, U.S. Geological Survey, called to our attention the article by Hay (1913), which locates the fossils in the National Museum under catalog No. 7819.
When the specimens were to be delivered to Charles Schuchert for donation to the National Museum by the Colorado Scientific Society, Hills wrote in a covering letter, "there are, however, some cranial fragments with teeth of a horse and camel from the Pleistocene of the Huerfano basin which Mr. Schuchert can take." The italics are ours; thus, by use of the word "Pleistocene," Hills showed that by the earlier use of Pliocene, he meant Pleistocene. Frank C. Whitmore, Jr., kindly examined the camel and horse bones for us and reported (written commun., 1968) that the recorded range of $C$. huerfanensis is compatible with the supposed Yarmouth age of the type $O$ Pearlette ash. Whitmore found the horse fragments to be typical of Equus (Asinus). At our request, he scraped some of the matrix from a cavity in a tooth of the type specimen of Camelops huerfanensis (Cragin). This matrix material was examined by Ray E. Wilcox, who wrote (written commun., 1969) that it

*** consisted of fragments and chips as large as $2 \mathrm{~mm}$ in diameter, some smooth resinous brown, others cemented aggregates of buff and white material. A few glass shards could be seen in the light-colored aggregates.

A portion of the sample treated with $6 \mathrm{~N} \mathrm{HCl}$ effervesced briefly, and the brown fragments dissolved or dispersed. From 10 to 20 percent of the insoluble material consisted of glass shards, the remainder of lumps of porous white material and a few fragments of quartz, feldspar, mica, and hornblende, none with the adherent glass that would show them to be phenocrysts belonging to the glass shards.

Glass shard types included bubble walls and wall junctions, vesicular and stretched vesicular types similar to those sketched by Swineford and Frye (1946, p. 24, figs. 2, 3) for Pleistocene ashes of the Central Great Plains (the "Pearlette ash"). Several hollow spheres were seen. Refractive index of the shards was predominantly 1.499 to 1.500 with a few as low as 1.498 and as high as 1.501 .

These characteristics of the shards (shape and refractive index) are common to several ash-fall deposits of different ages, including the socalled "Pearlette ash." It would be difficult to assign the volcanic shards in this fossil matrix to a particular one of these several ashes, since the sample is too small to furnish usable amounts of diagnostic phenocrysts, normally present in only very small proportion in the pure ash.

McCulloch (1963) reported finding two deposits of volcanic ash-one in the NW $1 / 4$ secs. 8 and 9 , T. $26 \mathrm{~S}$., R. 70 W., and another in the SE $1 / 4$ sec. 10, T. 25 S., R. 70 W., both in Huerfano County, Colo.-which he believed was the ash referred to by Hills. McCulloch sent a sample of the ash from sec. 9 to Howard A. Powers, U.S. Geological Survey, who concluded that the sample certainly had the composition of the Pearlette.

In June 1969 Scott visited three of the ash localities and collected additional samples of ash. In the NW $1 / 4$ sec. 9, T. 26 S., R. $70 \mathrm{~W}$., fragments of a mammalian skull and possible cervical fragments were found in the ash. G. Edward Lewis, who studied these bones, stated that "An orbital fragment seems to have more in common with the camelids than with other families." Only about 20 feet from the locality of these bones is a large pit in the volcanic ash. We suspect that this is the pit 
where J. Milligan (Cragin, 1892) collected Camelops huerfanensis (Cragin).

The volcanic ash is not associated with the Santa $\mathrm{Fe}(?)$ or the Devils Hole Formation and does not crop out anywhere near them. We found no stratigraphic or geographic basis for correlating the ash with those two formations.

According to Glen A. Izett, U.S. Geological Survey (oral commun., 1972), the index of refraction and the glass chemistry of the ash matches those of a family of Pearlette ashes, particularly type $\mathrm{O}$ ash and definitely not type S ash (Naeser and others, 1971). In addition, the ash in Huerfano Park lies in an old terrace gravel nearly 250 feet above Muddy Creek-the same geomorphic position as that of other outcrops of type O Pearlette ash in the Verdos Alluvium (Scott, 1963) near Denver. Seemingly this geomorphic position excludes the possibility of the Huerfano Park ash being type $B$ Pearlette ash. The definite Pleistocene age of $C$. huerfanensis, the inferred Yarmouth age of the type $\mathrm{O}$ Pearlette ash, and the lack of stratigraphic or geographic basis for correlation with any older volcanic-bearing formation all demonstrate that the camel should not be used as a guide to the age of any formation other than the fluvial gravel containing the type $O$ Pearlette volcanic ash.

In 1970 two more outcrops of type $\mathrm{O}$ volcanic ash were discovered-one by Scott in Verdos Alluvium along Grape Creek in a gravel pit in the $\mathrm{SE}^{1 / 4} \mathrm{SW}^{1 / 4}$ sec. 7, $\mathrm{T}$. $22 \mathrm{~S} .$, R. $72 \mathrm{~W}$., and the other by Lloyd A. Hershey in Verdos Alluvium in a gravel pit in the $\mathrm{SW}^{1 / 1} / 4$ sec. 4, T. 23 S., R. 72 W., Custer County, Colo.

\section{GEOLOGIC HISTORY}

The Tertiary geologic history of the Wet Mountain Valley and adjoining ranges records intermittent tectonism, brief volcanism, deep erosion in the mountains, and basin filling. The Wet Mountain Valley and Huerfano Park are parts of a single structural entity that apparently began to form as a tectonic depression in latest Cretaceous time. This depression subsided between the slowly rising ancestral Sangre de Cristo Range on the west and the Wet Mountains, the Greenhorn anticline, and perhaps the Apishapa arch on the east. The Echo Park Alluvium was deposited in this basin in Eocene time. The coarse grain size of the clastic materials from the Wet Mountains in Huerfano Park suggests that the Wet Mountains stood higher than the ancestral Sangre de Cristo Range, especially near the end of this period of basin-fill deposition.

Volcanism started in early Oligocene time, when several centers were active along the borders of the basin. The Devils Hole Formation, chiefly made up of pumiceous alluvial detritus in Huerfano Park but con- taining pumiceous lahars south of Rosita, originated from vents near Rosita. It is confined to a broad paleovalley between Precambrian rock walls within 5 miles of the source, but the deposits spread more widely on Eocene basin-fill rocks in the broader, southern part of the basin. The Deer Peak Volcanics, chiefly andesite and latite in composition, consist of flows and lahars that radiated away from the Deer Peak volcano and followed narrow paleovalleys incised into the Precambrian rocks of the Wet Mountains. South of Rosita, the Deer Peak interfingered with the Devils Hole. Volcanic rocks accumulated around other centers at Rosita and at Silver Cliff. Ash-flow tuffs like those in the Thirtynine Mile volcanic field spread into the north end of the Wet Mountain Valley graben and flowed across the future axis of the Sangre de Cristo Range from the west; these tuffs interfingered with flows that issued from faults at the graben margins. On the De Weese Plateau the early Tertiary drainage patterns were modified both by faulting and by the accumulation of volcanic detritus. One channel near Johnson Gulch northeast of Silver Cliff was blocked by faults, and in the resulting basin a small but thick deposit of water-laid ash accumulated. The volcanic vents in the Wet Mountain Valley apparently became inactive later in the Oligocene, and the younger basaltic volcanic flows in the Thirtynine Mile field did not reach south into this area.

The earliest postvolcanic deposits-the lower part of the Santa Fe(?) Formation near Goat Creek-were deposited on the volcanic rocks with little discordance. Channels across the site of the Sangre de Cristo Range were disrupted. The graben continued to subside during deposition of the Santa $\mathrm{Fe}(?)$, as shown by the fact that the upper part of the unit apparently discordantly overlaps the older part. We infer that this deposition took place in early Miocene to late Pliocene time. The modern Sangre de Cristo Range was uplifted to form a range towering above the valley in late Cenozoic time; movement began in early Miocene and continued until late Pliocene, when major uplift took place. Downfaulting of the graben continued into late Tertiary and Quaternary time.

In late Pliocene and Quaternary time the basin fills in the Wet Mountain Valley and in Huerfano Park were for the first time extensively dissected by streams. Huerfano Park was more deeply dissected because the principal barrier to the east, the Greenhorn anticline, was easily breached by the Huerfano River. The relatively minor drainages of Grape and Texas Creeks draining the Wet Mountain Valley were less able to cut through the resistant Precambrian rocks along their lower courses, and they now follow circuitous routes to the Arkansas River. In addition, the flood of glacial drift from the Sangre de Cristo Range in Quaternary time overloaded these streams and further inhibited downcutting. 


\section{REFERENCES CITED}

Berner, Robert, and Briggs, L. I., Jr., 1958, Continental Eocene sedimentation in Huerfano Park, Colorado [abs.]: Geol. Soc. America Bull., v. 69, no. 12, pt. 2, p. 1533-1534.

Boyer, R. E., 1962, Petrology and structure of the southern Wet Mountains, Colorado: Geol. Soc. America Bull., v. 73, no. 9, p. 1047 . 1069.

Briggs, L. I., Jr., 1965, Heavy mineral correlations and provenances: Jour. Sed. Petrology, v. 35, no. 4,p. 939-955.

Briggs, L. I., Jr., and Goddard, E. N., 1956, Geology of Huerfano Park, Colorado, in Rocky Mtn. Assoc. Geologists Guidebook 1956: p. 4045.

Burbank, W. S., and Goddard, E. N., 1937, Thrusting in Huerfano Park, Colorado, and related problems of orogeny in the Sangre de Cristo Mountains: Geol. Soc. America Bull., v. 48, no. 7, p. 931976.

Chapin, C. E., and Epis, R. C., 1964, Some stratigraphic and structural features of the Thirtynine Mile volcanic field, central Colorado: Mtn. Geologist, v. 1, no. 3, p. 145-160.

Cragin, F. W., 1892, Observations on llama remains from Colorado and Kansas: Am. Geologist, v. 9, p. 257-260.

Cross, Whitman, 1890, Geology of the Rosita Hills, Custer County, Colorado: Colorado Sci. Soc. Proc., v. 3, p. 269-279.

1896, Geology of Silver Cliff and the Rosita Hills, Colorado: U.S. Geol. Survey 17th Ann. Rept., pt. 2, p. 263-403.

Epis, R. C., and Chapin, C. E., 1968, Geologic history of the Thirtynine Mile volcanic field, central Colorado: Colorado School Mines Quart., v. 63, no. 3, p. 51-85.

1974, Stratigraphic nomenclature of the Thirtynine Mile volcanic field, central Colorado: U.S. Geol. Survey Bull. 1395-C (in press).

Greene, John, and Langefeld, R. M., 1956, Correlation chart Raton Basin and adjacent areas, in Rocky Mtn. Assoc. Geologists Guidebook 1956: p. 7.

Guyton, J. S., Hutton, J. R., and Sokolsky, G. E., 1960, Geology of the Devils Hole area, Custer and Huerfano Counties, Colorado: Michigan Univ. M. S. dissert., 81 p.

Hay, O. P., 1913, Camels of the fossil genus Camelops: U.S. Natl. Mus. Proc., v. 46 , no. 2025 , p. 267-277.

1924. The Pleistocene of the middle region of North America and its vertebrated animals: Carnegie Inst. Washington Pub. $322 \mathrm{~A}, 1924,385 \mathrm{p}$.

Hills, R. C., 1888, The recently discovered Tertiary beds of the Huerfano River basin, Colorado: Colorado Sci. Soc. Proc., v. 3, p. $148-164$.

1889, Additional notes on the Huerfano beds: Colorado Sci. Soc. Proc., v. 3, p. 217-223.

Johnson, J. H., 1937, The Tertiary deposits of South Park, Colorado, with a description of the Oligocene algal limestones [abs.]:
Colorado Univ. Bull., v. 25, no. 1, Gen. Ser. 403, p. 77.

Johnson, R. B., 1969, Geologic map of the Trinidad quadrangle, south-central Colorado: U.S. Geol. Survey Misc. Geol. Inv. Map I-558.

Johnson, R. B., and Wood, G. H., Jr., 1956, Stratigraphy of Upper Cretaceous and Tertiary rocks of the Raton basin, Colorado and New Mexico: Am. Assoc. Petroleum Geologists Bull., v. 40, p. $707-721$.

McCulloch, D. S., 1963, Late Cenozoic erosional history of Huerfano Park, Colorado: Michigan Univ. Ph.D. dissert. 158 p.

MacNish, R. D., 1966, The Cenozoic history of the Wet Mountain Valley: Michigan Univ. Ph.D. dissert. 120 p.

Munger, R. D., 1965, Structural geology of the Spread Eagle Peak area, Sangre de Cristo Mountains, Colorado: Mtn. Geologist, v. 2, no. 1, p. 3-21.

Naeser, C. W., Izett, G. A., and Wilcox, R. E., 1971, Zircon fissiontrack ages of Pearlette-like volcanic ash beds in the Great Plains: Geol. Soc. America Abs. with Programs, v. 3, no. 7, p. 657.

Robinson, Peter, 1963, Fossil vertebrates and age of the Cuchara formation of Colorado: Colorado Univ. Studies Ser. Geology, no. 1, p. 1-5.

1966, Fossil mammalia of the Huerfano Formation, Eocene, of Colorado: Yale Univ. Peabody Mus. Nat. History Bull. 21, 95 p.

Scott, G. R., 1963, Quaternary geology and geomorphic history of the Kassler quadrangle, Colorado: U.S. Geol. Survey Prof. Paper 421A, p. 1-70.

1970, Quaternary faulting and potential earthquakes in eastcentral Colorado, in Geological Survey research 1970: U.S. Geol. Survey Prof. Paper 700-C, p. C11-C18.

Siems, P. L., 1967, Volcanic and economic geology of the Rosita Hills and Silver Cliff districts, Custer County, Colorado: Colorado School Mines Ph.D. dissert., T1042, 222 p.

1968, Volcanic geology of the Rosita Hills and Silver Cliff district, Custer County, Colorado: Colorado School Mines Quart., v. 63 , no. 3, p. 89-124.

Stark, J. T., Johnson, J. H., Behre, C. H., Jr., Powers, W. E., Howland, A. L., and Gould, D. B., 1949, Geology and origin of South Park, Colorado: Geol. Soc. America Mem. 33, 188 p.

Steven, T. A., and Epis, R. C., 1968, Oligocene volcanism in southcentral Colorado: Colorado School Mines Quart., v. 63, no. 3, p. 241-258.

Swineford, Ada, and Frye, J. C., 1946, Petrographic comparison of Pliocene and Pleistocene volcanic ash from western Kansas: Kansas Geol. Survey Bull. 64, pt. 1, p. 1-32.

Van Alstine, R. E., 1968, Tertiary trough between the Arkansas and San Luis Valleys, Colorado, in Geological Survey research 1968: U.S. Geol. Survey Prof. Paper 600-C, p. C158-C160.

Volckmann, R. P., 1965, Geology of the Crestone Peak area, Sangre de Cristo Range, Colorado: Michigan Univ. Ph. D. dissert., 115 p. 
